\title{
Co-operative schools: democratic values, networks and leadership
}

\section{Tom Woodin, UCL Institute of Education}

\section{t.woodin@ucl.ac.uk}

\begin{abstract}
For over a decade, co-operative schools have struck a note of discord within the highly orchestrated context of English education policy. They encapsulate an old set of ideas but re-articulate them for new times by engaging with educational frameworks which are locked into the so-called global education reform movement (GERM) based upon on standards, standardisation, a mixture of centralised and devolved accountabilities, leadership, testing and accountability. Yet co-operative schools ostensibly aim to embed a set of wide-ranging values and principles: equality, equity, democracy, self-help, self-responsibility and solidarity as well as the principles of education, democratic control and community ownership, all of which echo the history of labour movements. The co-operative legal model not only adheres to co-operative values and principles but necessitates stakeholder involvement in the governance of schools: pupils, staff, parents, community and, potentially, alumni are all expected to play a role. These are compared to David Hargreaves' ideas about a 'self-improving school system'. I analyse the emergence of the co-operative network and the reasons for its dramatic growth alongside the complex problems it faced. In turn these help us to understand the possibilities and contradictions inherent in attempts to build inclusive and democratic educational networks.
\end{abstract}

For over a decade, co-operative schools have struck a note of discord within the highly orchestrated context of English education policy. They encapsulate radical and democratic ideas but re-articulate them for new times within the so-called global education reform movement (GERM) which is based upon on standards, standardisation, a mixture of centralised and devolved accountabilities, leadership, testing and accountability (Sahlberg 2012). The study of co-operative schools offers unique insights into the changing relationships between leaders and the networks in which they operate. It provides a 
useful vantage point to assess the neoliberal assumptions that privilege leadership as the necessary means to educational improvement, irrespective of context and relationships.

As a movement without a clear centre of power, a precise definition of co-operative schools remains elusive. It lies in processes as much as finished products, means as well as ends. Important starting points are the legal models for co-operative schools which have been authorised by the Department for Education. Co-operative trusts have brought together groups of schools that remain under the umbrella of the local education authority while allowing for the ownership of land and capital as well as enhanced partnerships and collaboration both with schools and other organisations. Co-operative academies apply co-operative ideas to what have been termed 'independent state schools' which are directly accountable to the DfE and enjoy independence over curriculum, staffing and, in theory, admissions. Crucially, all co-operative schools ostensibly aim to embed a set of wide-ranging values and principles: equality, equity, democracy, self-help, self-responsibility and solidarity as well as the principles of education, democratic control and community ownership, all of which echo the history of labour movements. In addition, voices which have been marginalised from schooling are reintroduced on new terms. The legal documents stipulate stakeholder involvement in the governance of schools by pupils, staff, parents, community and, potentially, alumni.

A sense of common ownership, inclusive democracy and mutuality underpin good co-operative schools which have aspired to embed co-operative values in their ethos, structure, curriculum and pedagogy although the exact mix in each school has not been preordained (Woodin 2015). Cooperative schools have been an important example of 'democratic experimentalism' which places responsibility and agency upon the shoulders of key stakeholders in education (Fielding and Moss 2011). The most enthusiastic co-operative schools have commonly presented themselves in terms of social justice. The application of co-operative values and principles have levered open arenas of debate and deliberation on what an inclusive and mutual system of education might look like, now and in the future, with ownership, equality and democracy never being far from the service. Critics of education policy have tended to concentrate more upon critique than what a socially just alternative might look like (Francis, Mills and Lupton 2017). Of course, co-operative schools have not provided 
simple answers or straightforwardly abolished contradictions, for example, in attempting to balance equity and equality to ensure an inclusive education for all. But they do provide spaces where these contradictions can circulate and be debated. Co-operative values are outward facing and invite criticism and comment from all stakeholders, not least those advocates of inclusion (Mills 2016). In addition, given the wide variety of meanings of inclusive education, described as an 'assembly hall' (Slee 2018: 11), there is a need to engage with the interconnections between broad and narrow definitions of inclusion and co-operative school networks offer an opportunity to do this.

The co-operative model was not a top down one and allowed individual schools, and groups of schools, to define their own solutions by adapting the legal requirements to their needs. This was a radically different experience to that of schools which potentially lost their independence in perpetuity through being 'sponsored' by a dominant academy partner. Moreover, the production of a Cooperative Identity Mark (CIM) and a partnership with Edison Learning recognised that becoming cooperative was not an automatic change resulting from new nomenclature rather than a gradual and reflexive process which took time and resources. To add to the complexities of definition, the Cooperative Group, Britain's largest consumer co-operative, does also directly sponsor a network of academy schools, which are not considered here.

The difficulty in delineating co-operative schools also arises from the fact that they are not fullyfledged co-operatives despite the fact that Co-operativesUK, the umbrella body for co-operatives, has categorised them as such (Co-operativesUK 2015). Whereas the general values have appealed to school leaders as encapsulating the historical vocation of state schools, a strict application of cooperative principles, for instance, on autonomy or ownership by members, is an impossibility under current legal regulations. Similarities to non-co-operative schools can also be identified which reduces their distinctiveness (Coates 2017). Accordingly, they can be characterised as 'hybrid' or 'incipient' co-operatives (Woodin 2015). It is this ambiguity in definition which helps us to explain how they rose to prominence in the school system.

Co-operative schools have not been easily marginalised as an interesting and unrealistic experiment subsisting on the margins of society (Woods 2015). On the contrary, from 2008, when the first co- 
operative school was established in Reddish Vale in Greater Manchester, the number rapidly increased to 850 , subsequently fell back to 600 and then to the 300 mark. The brisk time-limited growth makes it urgent to understand their nature, to highlight their potential as well as their drawbacks. It will help us to assess whether the recent decline represents an inner defect in the DNA of co-operative schools or whether external obstacles and an inhospitable climate has stifled their advance. A democratic model of education may need to build upon multiple short-lived initiatives in order to promote longer-term objectives (see Fielding and Moss 2011).

In a broader arena, co-operative schools point to contradictions inherent in the transition from post war welfare politics to one which nurtures privatisation and marketisation. Problematising the public, universalist common ownership model paradoxically unlocked new spaces in which co-operative ideas could gain a new foothold, particularly during the New Labour years when 'third sector' ideas were advocated involving co-operative and mutual enterprise, social enterprise and voluntary organisations (Ball 2007; Ridley-Duff and Bull 2011; Hatcher 2015). The shift was not entirely a result of government policy. From the 1990s, and especially since the 2007-8 financial crash, cooperatives and co-operative ideas have played a greater role in public life, with the formation of mutual trusts in welfare and leisure and the gradual mainstreaming of co-operative values and principles (MacPherson 1996; Co-operative Commission 2001; Birchall 2008; Woodin et al 2010). Co-operative schools themselves were constructed upon the collaborative cultures and informal alliances between schools which hovered under the radar of market friendly government policy (Hadfield and Chapman 2009; McCormick et al 2011).

Networks have become a pervasive way of understanding contemporary social life, ostensibly replacing hierarchical forms of organisation based upon class and bureaucracy. While networks are as old as human society, in recent decades it has been argued that digital technologies have facilitated new relationships based upon flows of information, people and resources between hubs which also demarcate new educational spaces as constituents of a 'network society' (Castells 2000). The unleashing of neoliberalism has redefined the role of the state in relation to wider networks of power and influence which cannot be defined in advance but are more about governing and assembling 
transnational fluid networks - neoliberalism as a mobile technology (Ong 2008; also Frankham 2006; Ball and Olmedo 2011; Ball 2016).

Within the GERM framework, the entrepreneurial super-head has been presented as offering solutions to urgent social problems by injecting efficiency and flexibility into public services (Earley and Greany 2017; Courtney et al 2018). The unremitting focus upon the able leader partly resulted from a new mode of conceiving the social world. In the early 1990s, Anthony Giddens (1991) captured the mood in arguing that modernity had nurtured a 'reflexive project of the self' by which individuals sustain coherent and continuously revise their biographical narratives. Increasingly, the ties between these creative individuals and their institutional sources of power were to be shrouded in discourses that asserted improvement was possible through leadership alone.

By contrast, the co-operative schools network designed spaces within which schools could contend with dominant ideas and practices of leadership. They bring to the surface a connection between leaders and led, between the individual and the milieu in which they circulate. This is hardly a new insight. It is paradoxical that the voluminous scholarship on leadership has long acknowledged the collective forces which underpin the individual leader. For instance, in 1925 Mary Parker Follet (1925) argued for a 'conception of power-with, a jointly developed power, a coactive, not a coercive power'. Leadership is dependent upon followership as part of multiple relationships between changing constituencies (see summary in Carter et al 2015). In this vein, Ron Glatter (2006) and Rob Higham (2013) have directed our attention towards the organisational and institutional contexts within which educational leadership is formed and channelled.

David Hargreaves (2010, 2011, 2012a, 2012b) articulated an influential position which married leadership with the necessity and possibility of building a 'self-improving school system' (SISS). It spoke to the interests of policy makers who, having undermined local education authorities and fostered an unsustainable system based upon a multiplicity of complex individual contracts with academies and free schools, welcomed more systemic approaches. Regional schools commissioners and moves towards multi-academy trusts reflect this shift in thinking. Hargreaves argued that a SISS did not simply mean that schools co-operated with each other but engendered a systemic element: 
'clusters of schools accepting responsibility for self-improvement for the cluster as a whole' which would constitute nothing less than a new 'middle tier' between the school and local government (Hargreaves 2010, 5). There were to be four elements of this new system: capitalising on the benefits of clusters; local solutions; co-construction between schools; and system leadership. Skilful system leadership was central to educational re-organisation and to balance collaboration and competition between clusters (Hargreaves 2010, 8). Indeed, Hargreaves looked forward auspiciously in comparing 'the previous era of school improvement' to the 'new era of systemic self-improvement (Hargreaves 2010, 22). Effective partnerships and collaborations were to be based upon moral purpose, trust, reciprocity and even the involvement of stakeholder groups in schools, all of which were resonant with aspects of co-operative schools. Similarly, Hargreaves argued that a prerequisite for effective partnerships was a 'theory of the case' (Hargreaves 2012a, 5) which bore resemblance to plans to infuse co-operative values into schools. Hargreaves' think-pieces were published by the National College for School Leadership and appeared on the website of the Department for Education. The final of the four papers confidently proclaimed that the system was moving 'towards maturity'. However, a few years on, the English education system is fare from systematic. The interconnections between building a network and the forms of leadership which then become necessary and possible are only partly examined. The specific nature of leadership in co-operative schools, framed by a unique network, and articulating older traditions, has been little understood.

\section{Methodology}

Critical sociological and historical approaches help us to comprehend the shifting nature of leadership within the co-operative network in which both structure and agency have been visibly interconnected. I have followed the origins and trajectory of the co-operative schools movement over an extended period, from its inception in the early years of the twenty first century. As such, this research represents a network ethnography (Ball 2012; 2016), although social movement ethnography is more accurate. It necessarily pays attention not just to the actual journey the movement has taken but also to the longer-term resources and ideas on which it draws, including the history and values of co- 
operation (Yeo 1988; Gurney 1996; Woodin 2011; Wilson et al 2013). The ways in which these resources have been adapted and deployed in contemporary settings helps us to see the interconnections between past and present (Silver 1990; Brooks 1991; Higham and Yeomans 2007; Woodin et al 2013).

This project has involved web searches, visiting schools, interviewing school leaders, teachers, pupils, administrators, facilitators and organisers. I have attended training and information sessions as well as conferences and seminars, many of which I organised. Observations and a critical analysis of key documents and publicity have furnished essential insights into the route that schools have attempted to chart (McCulloch 2004). Discussions with participants at conferences as well as organisers and facilitators of the movement meant that I could hone in on examples of schools which were interested in working with co-operative values. Through strategic sampling I selected the schools most openly committed to co-operative values and principles (Mason, 2002). I was not attempting to capture the movement in a straightforward representative way but to examine critically key examples of schools which had progressed the furthest in terms of applying co-operative values. This helped to make visible key contradictions and tensions which suffused the movement as a whole.

To date, I have carried out approximately 30 interviews which were conducted on an open-ended basis to ensure that, as far as possible, the research stayed close to the language and motivations of respondents, their schools and networks. The approach has furnished an understanding of the ways in which co-operative ideas were being understood and applied, if at all, in schools. Ten schools have been visited and many more discussions with school leaders, teachers and pupils have taken place away from schools. Here I concentrate upon material from five schools as well as from organisers and those involved in the co-ordinating bodies. Each of the schools is located in a so-called 'deprived' area - a southern small town (Pine School), a northern small town (Ash School), on the fringes of London (Alder School), in London (Larch School) and another on the edge of a northern city (Oak School). I also interviewed organisers and facilitators in the supportive co-operative agencies. In part this research was funded by a small grant from the Society for Educational Studies. 
The interview and documentary material was analysed via a critical analysis of key themes relating to networks and leadership. Summaries of the interviews allowed me to work directly with the oral recordings which reduced the possibility of transforming the source via transcription (Portelli 2016). The selection of themes and quotes emerged from an understanding of the history of the co-operative movement and co-operative education which afforded an essential means to understand the possibilities and limitations of co-operative schools (Woodin 2011; 2019 forthcoming).

\section{Origins: material and intellectual}

Co-operative schools did not simply spring up after someone had a good idea. The formation and development of any network requires a judicious mix of material and intellectual resources. Alternative models and voluntary initiatives find it hard to engage with any area of policy at short notice (Woodin et al 2010). While both state and market are ostensibly open to everyone to participate, the reality is more restricted. The confluence of resources, historical awareness and entrepreneurialism at any given historical moment are essential to success. Leadership must be plugged into an enabling network in which partners are able to lever resources and ideas and are ready to act upon opportunities incumbent upon changes in policy and society. Leaders are supported by and deploy various 'forms of capital' - economic, social and cultural - which Pierre Bourdieu (2004) succinctly described.

At the outset, the resources at the disposal of the co-operative schools network were much greater than many equivalent 'voluntary' networks. The Co-operative College had a long educational history and had worked with schools, for example through the Schools' Curriculum Industry Partnership (SCIP). It was established in 1919 and emerged out of an educational ferment stretching back to the early nineteenth century. A tangible movement was held together with set of coherent values and principles which constituted an alternative form of 'cultural capital', albeit one that did not immediately fit into the hierarchical explanation favoured by Bourdieu. The very process of building a movement inspired wide-ranging utopian visions of the future (Woodin 2011). In 2002, the chief 
executive and principal of the College had been harbouring ideas about establishing a network of schools and was ready and able to take advantage of changes in policy (CEO, discussion 2002). The College worked closely with specialist schools that formed a network of Co-operative Business and Enterprise Colleges across England, funded by the Co-operative Group, at a cost of around $£ 1$ million, a not insignificant sum. New ideas circulated around these actions. The initiative was tied into a curriculum reform project, also funded via co-operative networks, that used the global co-operative movement as a basis for new resources. Sharing knowledge and experience across a national network gave the movement kudos and sparked off new ideas as schools emulated one another. Social capital had been generated and contributed to the momentum as head teachers were eager to continue the network once the specialist schools initiative ceased.

The movement was now better-placed to take advantage of opportunities deriving from the incessant changes in education policy. The 2006 Education and Inspections Act permitted the formation of trust schools and a co-operative model was grafted onto this legislative opening, supported by Cobbett's, a legal firm which had previously worked on co-operative structures in public services. Co-operative trusts were established to facilitate the participation of a wide range of partner organisations. In addition, legal structures were developed for academies and free schools with many hybrid models being adapted for local use. It was not completely a top-down model but allowed partner schools to fashion their own networks, structures and priorities, placing differing emphases upon partnerships, pedagogy, culture and ethos. It endeavoured to stimulate self-help based upon the voluntarist tradition of the co-op (Co-ordinator 2010). A further boost was provided by the then secretary of state for children, schools and families and Labour-Co-op MP, Ed Balls, who offered $£ 500,000$ for training in schools unfamiliar with co-operative ways of working (Wintour 2008). Psychologically, it took some time for partner schools to grasp that they had to construct these networks themselves, having been socialised into the presumption that there would be one dominant sponsor in a network. The generation of the network was thus the result of a favourable configuration of resources, knowledge, ideas and capacities. In earlier decades, these factors had not been aligned. For example, when further education colleges became independent of local authorities in the 1990s, co-operative models had not 
been proposed and subsequently co-operators would view this as a lost opportunity (Co-ordinator 2010).

Ironically, the spread of co-operative schools was hastened by the 2010 Academies Act which paved the way to the potential academisation of all schools. This raised the alarm that schools would be compelled to cede their independence and autonomy indefinitely. The fear of being swallowed up by a predatory academy became a significant motivation alongside the positive reasons for going cooperative:

I thought that we had to do it, there was no option, even though academies are an anathema to me. It needed to happen because we needed to be able to dramatically rebrand ourselves, reframe ourselves and do all those kind of things. But we are also surrounded by a very rapacious chain... and we were well aware that they were looking for places to take over... so far away from what we believe in... We wanted something that reflected exactly what our values are and also that would protect us from a chain. The co-operative model seemed to be the one that actually fitted that. Now when I floated that, and floated the idea of academy status, the governors were very clear. They said, we can understand all the negatives and why you think that but you haven't given us the positives of why being a co-operative would be the right way. We went on a kind of a journey of discovery visiting... co-operative academies... co-operative schools in various parts of the country and put together what it was that made the difference (Headteacher, Larch School, 2014).

This was a head teacher deeply committed to comprehensive schools serving a local community. The intention was that co-operative status might help to protect the school from forced academisation and a violent shift in attitudes and values. This fear of isolation has been a common motivation for schools to join networks and reflects the dangers of trying to go it alone (Hadfield and Chapman 2009). However, alongside the fear existed hope, that co-operative values and principles might offer a way of retrieving and rearticulating democratic comprehensive schooling tied directly into a new conception of leadership, particularly involving the student body in a serious way in the running of schools and advising to head teachers on a range of issues (Teacher, Larch School 2014; see also Ralls 2016). 
In part then, the co-operative route was a means of unlocking leadership capacity. Beyond the individual school, the leadership supplied by the co-operative movement was considerable and drew upon experience of operating in formal settings

Network is the real power of the co-operative movement. And they've got some really formidable people. [The local authority] weren't going to allow us to convert to an academy... because I was new in post and the school hadn't ever got above $38 \%$ [5 A-C in GCSE, the national examinations taken at age 16] so they said, 'No ... we don't trust you to convert because we only want schools that are going to get great results to convert'. But actually the co-op came and stood by my side when the local authority were putting pressure on me to join a chain and said, 'Leave her alone, this school is part of a co-operative trust' ... and actually protecting me... There's some formidable people in the co-op with a lot of expertise at dealing with the DfE and local authorities nationally, I think that is also quite a powerful organisation to belong to actually (Headteacher, Pine School 2014).

This quote discloses a dark side of education policy in cajoling schools, restricting choice and favouring certain alliances. School leaders noted that civil servants directly briefed against cooperative schools after 2010 (Co-ordinator 2016). The quote also highlights the vulnerability of individual schools and their exposure to pressures from officials at the DfE and elsewhere. Local authorities have been undermined by centralisation but some have found it necessary to actively support this direction of travel. Standing up to officials, who invoke the power and ideology of the state to justify their assertions and proposals, was not straightforward and entailed vision, knowledge and experience. Thus, the co-operative network was an important source of external support for schools. Interestingly, the school in question would go on to achieve and sustain impressive examination results, even by Ofsted standards (Headteacher, Pine School 2014).

Internally, moral purpose and 'unconditional giving' was cultivated by co-op schools and their supportive structures (Headteacher, Oak School 2012). The Schools Co-operative Society was created 
along national and regional lines. A chief executive position was established, and funded by the Cooperative Group for three years, and the College employed part time associate staff in each region. Conferences were held in Manchester at the Co-operative Group and attracted hundreds of people. Shared understanding and dialogue intensified across geographical areas, fed by a fascination with other schools as well as the safety of collaborating with non-competitors. The feeling of being part of something bigger was bolstered by the fact that becoming a co-operative school located them in the midst of a global movement, evidenced by international visits and partnerships in Europe and with developing countries. Visits to Spain and Italy, both countries with significant co-operative movements, became a regular feature for a time (Headteacher, Ash School 2012). It helped to make sense of co-operative ideas as part of a vibrant and changing movement. Head teachers felt empowered to swim against the tide of education policy and to invoke co-operative support mechanisms:

if one primary school starts to fail, what seems to happen in a cluster is that the other four will go, 'Tee hee hee, he's failing shall I get his kids?' Publicly they'll go, 'Isn't it a shame about Bloggin's school'. But, if you are tied into a co-operative and the glue is holding you together you are duty bound to say look we are going to have to look after that school down the road, what can we do about it? Are we going to send one of our staff in to help prop them up or can we get some advice? How is that process going to work? rather than just ignore them. If it comes to the awful decision that a school has to shut because of low numbers; because it owns the assets 'the assets remain in the community and are not gobbled up by County HQ. All those decisions become community driven (Headteacher, Ash School 2012).

The quote underpins the importance for leaders of locating values and identity within schools and communities. The glue metaphor is also used by Hargreaves. Yet, the within the co-operative movement, leadership was placed within a network of schools as well as a local community which belied the widespread claims being made for individual leaders. Consequently, co-operative schools were beginning to think about how trusts connected them to wider communities (Glatter 2017). Of course, there were limitations and many obstacles to face (Woodin 2012; Facer et al 2012; Woodin 
2015; Davidge 2016/7). But the movement had been ambitious in crafting alternative structures based upon co-operative ways of working. The broader vision of coherent and systemic change lent a significance to actions that, on their own, might have been considered unremarkable.

\section{Structures and movement}

These were only the beginnings of a movement which remained partly constructed. As one headteacher noted in 2016, the movement was still 'emerging rather than being embedded' (Headteacher, Alder School 2015). From 2013-14, it was to be beset by unforeseen problems. Quadrupling the number of schools in a short space of time exacerbated and exposed internal contradictions. The surge of membership, partly to avoid academisation, created a structural imbalance and affected the capacity to maintain mutually beneficial relationships which were essential to long term development. It proved difficult to sustain the network on a firm footing as the coming together of various partners started to diverge following a period of excitement. Internal dilemmas were compounded by external critics who aimed to undermine and wrong foot co-operative schools.

Structural imbalances were inherent in the movement. It had always been an opportunistic option for some schools that remained unsure about the full potential of the co-operative difference. The schools quoted above were some of those most keen to explore a co-operative conception of education. It was not a vision fully shared by all and the proliferation of co-operative schools did not translate into greater levels of overall participation. This is not to imply that other schools were necessarily uninterested in the wider vision, just that they were not ready to make sudden step changes in their thinking and organisation.

Given the risks and responsibilities that schools faced, expecting them to build a self-help network in a short space of time, within a hostile, political environment, was also a tall order. There were differences of agreement over the amount of support that schools could and should be able to access. The belief that taking on a co-operative identity would shield schools from academisation proved to 
be only partly true. Poorly performing and 'coasting' schools found that they could be integrated into other chains, swallowed up by multi-academy trusts (MATs) with very different priorities and values. In forging these new relations, policy makers showed little respect for co-operative values in comparison with religious schools for which it would have been unthinkable to coerce into alliances with contrary values (Co-operative speaker, seminar 2016). The co-operative network did sponsor poorly performing schools, which met with scepticism at the DfE. Logistically the network had not been set up to support 'failing' schools nor was it ready to do so on a widespread scale.

In addition, the voluntary nature of the movement made co-ordination problematic. The number of cooperative schools dwarfed the resources in the centre of the movement. Many ideas were floated about sharing services, joint procurement and teaching partnerships which might have garnered income for the centre, but these were hard to organise on the basis of voluntary participation where schools had to opt in (Co-ordinator 2010; Headteacher, Ash School 2012). No two member schools or structures were the same which meant there was a diversity of structures, priorities and needs.

Though the rationale for co-operative schools emphasised self-help and mutual support, the creation of the Schools Co-operative Society was not simply a result of demands from the membership. It involved a fair amount of top-down initiative which also helped to convince schools that there could be benefits in joining this movement. The ideas and funding were already in place with the support of the Co-operative Group. Many schools initially joined the SCS but gradually became reluctant to pay subscription fees for an unknown resource (Co-ordinator 2016; Organiser 2018). In fact, from the beginning, some schools expected more support from the centre of the movement, for instance, from a support worker. Schools were eager to identify the immediate benefits in contributing to wider networks

It's great to be part of a Co-operative National and International Schools Network but cooperation is hard work, nobody wants to go to a networking meeting just to feel good - how is this going to benefit our children, what's the direct impact of being part of this wider network; and then our wider strategic alliances as a group of schools. 
The meetings tend to be fairly short and they tend to be in Manchester. I think 'is it a good use of my time going to Manchester for a two hour meeting?' ... I hope I'm not sounding selfish but ... it's got to make a difference (Headteacher, Oak School 2012).

The strategic support which might have helped the network to flourish could not easily be provided by member schools for uncertain returns. It was difficult for the SCS to make the transition from start-up funding to subscriptions:

Apex bodies have no right to exist. They survive or fail based on whether they meet their members' needs. There is an acid test for this. When you move to be a subscription-based organisation, it's not the first years' subscriptions when everybody is actually saying this looks like a brilliant idea. It's when the second and third years' subscription requests go out and it's, 'What did the Romans do for me?' It's as straightforward as that and when you tie that with how much tighter the budgets are going to get for schools... it's got to be delivering value overall (CEO, 2016).

In Spring 2019, the website of the Schools Co-operative Society was taken down. In recent times, education policy has accurately identified that schools on their own are vulnerable and policy has aimed to lever additional resources into schools through sponsorship and governance. Public strategies are being replaced with private philanthropy. Co-operative schools illustrate that there have been different ways of achieving this objective which problematise both public and private.

The respective relations between the centre, individual schools and regions remained provisional and could not be imposed from above but depended upon voluntary agreement among schools. In some areas there were strong local networks for a time, notably in Cornwall and Yorkshire and Humberside. Regional networks were supported by a part time associate working via the College. In the south east, LASER (London/South East regional network) developed a more sustainable model based upon subscriptions and providing services, supported by strong leadership. This gave rise to debates about 
the ownership of the movement and the respective relations between centre and regions where a diverse range of potential models were forming along different lines.

Subsequently, in 2017, the Co-operative College would virtually withdraw from its support role. The substantial cultural and social capital of the College had sometimes been shrouded behind the veil of the Schools Co-operative Society which was not fully operational. Having said this, only 1.5 core staff at the Co-operative College were devoted to co-operative schools in addition to the regional associate staff (Coates 2015). From the outside it looked like a much larger organisation and the principal of the College used to joke that the Department for Education had wrongly assumed that the reach and scope of the College was greater than in fact it was (CEO 2016). Income deriving from support during the conversion process dried up with the lack of new recruits and it proved difficult to sustain this work financially (Organiser 2018).

The proliferation of co-operative schools halted with the financial and reputational damage done to the co-operative movement in 2013 (Co-operative Group 2014a and 2014b). The Co-operative Group also became more ambivalent about the co-operative schools movement and perceived dangers in having such a widespread and inchoate network that was expanding so speedily. Put simply, there was a reputational risk, and the Group felt more secure directly sponsoring its academy schools. It had little control or influence over the wider movement of schools for which it felt there was a danger that it would be seen as responsible. Group staff found it unnerving that newly established co-operative schools would mistakenly contact them for funding (Co-op organiser 2010). One Group employee was aware of co-operative trust schools that 'sadly carry that name in name only', exposing hesitancy about the 'co-operative difference' of these schools (Harvey 2017).

\section{Conclusion}

Co-operative schools have operated within and against English education policy. The co-operative project actively works to improve standards but also explicitly raises the importance of culture and values beyond purely instrumental purposes. The process of change involves the transformation of 
pupils and schools in contradictory ways. Co-operative visons, structures and practices carry the potential to forge new relationships based upon inclusion and mutuality. Of course, the reality on the ground may differ markedly as schools have to face multiple issues including a restrictive policy context. Neoliberal thinking has seeped into the mentality of educators and students and the everyday school life (Woodin 2017). Rich examples of co-operation thus exist alongside more generic and uncertain co-operative action.

Despite the currently precarious position of co-operative schools, there are possibilities of re-grouping in new ways. Historically, co-operatives have been systematic and grounded in communities. Shared democratic values can also help to build visions beyond the local. Co-operative schools offer an organic model of growth which will be necessary if sustainable alternative models are going to be built. More than one experiment in democratic and inclusive education will have to be floated before workable structures and relationships emerge. There are historical parallels with the co-operative movement of the nineteenth century when multiple attempts at federating societies were made before successful examples emerged. Co-operative networks offer spaces in which wider contradictions can be debated and possible solutions evaluated.

The promise of co-operative systems which are grounded in local democratic practice but also address concerns facing contemporary education policy, offer scope for re-imagining what an inclusive system might look like. Co-operative and mutual networks have attempted to span the concern with public service as well as the quality of services. The potential emergence of a socially just education system will require many such democratic experiments if it is to flourish. An advantage of such a general approach also offers the possibility that specific practices of inclusive education can be considered alongside other markers of inequality. In this way, initiatives relating to disability might enjoy a greater coverage and start to be understood in relation to wider social change. While creating spaces for inclusive practices to be aired, debated and improved, is essential to a socially just education system, the danger for any such movement is that the period of formation is one in which schools are vulnerable to take-over if they do not meet their targets. They do not have decades to 
develop a workable mutual alternative but have to achieve this within extremely challenging circumstances.

The widespread assumption that self-sustaining systems can be created without sustained support, needs further analysis. Hargreaves repeats some of these errors in claiming that the 'self-sustaining system' was moving 'towards maturity' within just a few years. He found the policy landscape after 2010 to be 'exciting' $(2011,4)$ and based upon 'voluntary' participation and fluid federations $(2010$, 13). Of course, the small scale and temporary networks he describes did not constitute a new system. At times he views the various federations in neutral terms, underplaying the very hard-nosed reorganisation of schools. He is very forgiving about the actual nature of the relationships in schools, apparently blind to the fact that coercion and forced academisation was not a benign partnership. Although there are examples of positive partnerships in some MATs, the expansion of the cooperative schools movement operated as a reaction against the involuntary incorporation of schools into academy chains - it showed that not all was a rosy picture across the school system. Hargreaves' eagerness to learn from 'business' is largely restricted to capitalist for profit business, ignoring the diversity of enterprises which might be relevant to his case. As a result, the language of support and collaboration hides the constraining nature of regulation. It may be that the balance between voluntarism and compulsion in a co-operative network needs to be revisited, especially in an inhospitable policy climate. There is not always a short term or easy way of aligning the self-interest of members with the collective interests of co-operatives and community. If movements are to construct the various forms of capital necessary, time and resources will have to be devoted to fathoming co-operative solutions at the same time as external forces are held at bay. It is possible that a more sympathetic government might provide the safety, space and resources for schools and partner organisations to work out such a systematic co-operative approach.

The wider education policy landscape is also illuminated in new ways by this research. Forms of capital can be surreptitiously channelled by the state and its agencies in tune with policy priorities. Indeed, inequitable funding and hidden support, such as access to advisors, skews the system and ensures that free schools and favoured academies thrive, inviting comparisons with the way that 
governments in the 1960s used funding to support comprehensive schools (Woodin et al 2013). Leaders in these new networks can be invested with magical entrepreneurial qualities - as enablers and super heads - which in fact derive partly from their networks and support structures. Networks draw upon a tapestry of associationism stretching back to the enlightenment and beyond. The appearance of floating effortlessly on thin air is, in reality, underpinned by various forms of capital.

Co-operative schools also help us to understand the issues involved in market entry for alternative and inclusive practices within a competitive system. Anyone is in theory 'free' to establish enterprises in a 'market democracy', but only some are well-placed to do so in the likelihood that change will come about. In the 1990s, Rupert Murdoch and News Corporation were able to draw upon considerable organisational experience and networks, in addition to tabling over half a billion dollars up front, in establishing Fox News (Sherrill 1995). This option was hardly available to others. Current plans for a co-operative university are similarly attempting to identify initial funding, which is not insignificant (Organiser 2018). The theory and practice of market entry is highly dependent upon an astute mix of different 'forms of capital' - material resources and finance in addition to human, social and cultural capital. The results, however are not preordained. In opening up schooling to multiple partners and providers, there can be unexpected consequences even in highly regulated systems.

\section{References}

Ball, Stephen J. 2008. The Education Debate. Bristol: Policy Press.

Ball, Stephen J. 2016. "Following Policy: Networks, Network Ethnography and Education Policy Mobilities”, Journal of Education Policy 31 (5): 549-566. https://doi.org/10.1080/02680939.2015.1122232

Ball, Stephen. 2012. Global Education Inc. London: Rouledge.

Ball, Stephen J. and Antonio Olmedo. 2011. "Global Social Capitalism: Using Enterprise to Solve the Problems of the World", Citizenship, Social and Economics Education 10 (2/3): 83-90. http://dx.doi.org/10.2304/csee.2011.10.2.83.

Birchall, Johnston. 2008. "The Mutualisation of Public Services in Britain: A Critical Commentary", Journal of Co-operative Studies, 41 (2): 5-16. 
Francis, Becky, Mills, Martin \& Lupton, Ruth (2017) Towards Social Justice in Education: Contradictions and Dilemmas. Journal of Education Policy, 32 (4): 414-431. DOI: 10.1080/02680939.2016.1276218

Bourdieu Pierre. 2004/1983. "The Forms of Capital", in Stephen J. Ball. ed. Chapter 1. The Routledge Falmer Reader in Sociology of Education. Abingdon: RoutledgeFalmer.

Brooks, Ron (1991) Contemporary Debates in Education: An Historical Perspective. London: Longman.

Carter, Dorothy R., Leslie A. DeChurch, Michael T. Braun and Noshir S. Contractor. 2015. "Social Network Approaches to Leadership: An Integrative Conceptual Review." Journal of Applied Psychology 100 (3): 597-622. https://doi.org/10.1037/A0038922

Castels, Manuel. 2000. The Rise of the Network Society: vol 1, The Information Age: Economy, Society and Culture, $2^{\text {nd }}$ ed., Oxford: Blackwell.

Coates, Max. 2015. The Co-operative: Good with schools? Management in Education 29 (1): 14-19. doi:10.1177/0892020614560839

Co-operative Commission. 2001. The Co-operative Advantage: Creating a Successful Family of Co-operative Businesses. London: Co-operative Commission.

Co-operative Group. 2014a. Report of the Independent Governance Review (Myners Report). Manchester: Co-operative Group.

Co-operative Group. 2014b. Failings in Management and Governance. Report of the Independent Review into the Events Leading to the Co-operative Bank's Capital Shortfall (Kelly Review), Manchester: Co-operative Group.

Co-operativesUK. 2015. The Co-operative Economy 2015: An Ownership Agenda for Britain. Manchester: Co-operativesUK.

Courtney, Steven J., Ruth McGinity and Helen M. Gunter. 2018. eds. Educational Leadership: Theorising Professional Practice in Neoliberal Times. Abingdon: Routledge.

Earley, Peter and Toby Greany. 1995. School Leadership and Education System Reform. London: Bloomsbury.

Facer, Keri, Julie Thorpe and Linda Shaw 2012. "Co-operative Education and Schools: an Old Idea for New Times?" Power and Education 4(3): 327-341. https://doi.org/10.2304/power.2012.4.3.327

Fielding, Michael and Peter Moss. 2011. Radical Education and the Common School. London: Routledge.

Follet, Mary Parker. 1925. "Power" in Metcalf, H C and L Urwick. eds. Chapter . Dynamic Administration: The Collected Papers of Mary Parker Follet. New York: Harper. 
Frankham, Jo. 2006. "Network Utopias and Alternative Entanglements for Educational Research and Practice", Journal of Education Policy, 21 (6): 661-677.

https://doi.org/10.1080/02680930600969191.

Giddens, Anthony. 1991. Modernity and Self Identity: Self and Society in the Late Modern Age. Cambridge: Polity Press.

Harvey, Rebecca. 2017. "Reimagining Education: The Case for Co-op Schools - and a UK University. 7 July. Co-operative News.

https://www.thenews.coop/120243/sector/reimagining-education-case-co-op-schools-ukuniversity/

Glatter, Ron. 2006. "Leadership and Organization in Education: Time for a Re-orientation? School Leadership and Management 26 (1): 69-83. https://doi.org/10.1080/13634230500492962.

Glatter, Ron. 2017. "Schools as Organizations or Institutions: Defining Core Purposes" in Peter Earley and Toby Greany. eds. Chapter 2. School Leadership and Education System Reform. London: Bloomsbury.

Gurney, Peter. 1996. Co-operative Culture and the Politics of Consumption in England 18701930. Manchester: Manchester University Press.

Hadfield, Mark and Christopher Chapman. 2009. Leading School-based Networks. London: Routledge.

Hargreaves, David H. 2010. Creating a Self-improving School System. Nottingham: National College for Leadership of Schools and Children's Services.

Hargreaves, David H. 2011. Leading a Self-improving School System. Nottingham: National College for School Leadership.

Hargreaves, David H. 2012a. A Self-improving School System in International Context. Nottingham: National College for School Leadership.

Hargreaves, David H. 2012b. A Self-improving School System: Towards Maturity. Nottingham: National College for School Leadership.

Hatcher, Richard. 2015. "The Transfer of Local Authority School Support Services to External Social Enterprises", Journal of Educational Administration and History 47 (4): 388413. https://doi.org/10.1080/00220620.2015.996864.

Higham, Jeremy and David Yeomans. 2007. "Policy Memory and Policy Amnesia in 14-19 Education: Learning from the Past?" in Raffe, David and Ken Spours. eds. Chapter 2. Policy Making and Policy Learning in 14-19 Education. London: Institute of Education.

MacPherson, Ian. 1996. Co-operative Principles for the 21st Century. Geneva: ICA

McCormick, Robert, Alison Fox, Patrick Carmichael and Richard Procter. 2011. Researching and Understanding Educational Networks. London: Routledge.

McCulloch, Gary. 2004. Documentary Research in Education, History and the Social Sciences. London: RoutledgeFalmer. 
Mason, Jennifer. 2002. Qualitative Researching. London: Sage.

Mills, Martin. (2015) The Tyranny of No Alternative: Co-operating in a Competitive Marketplace. International Journal of Inclusive Education, 19 (11): p. 1172-1189.

Portelli, Alessandro. 2016/1979. What Makes Oral History Different, in Thomson, Al and

Perks, Rob, The Oral History Reader. Abingdon: Routledge.

Ralls, Deborah. 2016. Developing Democratic Engagement in School: Can Becoming Cooperative Help? Forum, 58 (3): 363-370. http://doi.org/10.15730/forum.2016.58.3.363

Ridley-Duff, Rory and Bull, Mike. 2011. Understanding Social Enterprise: Theory and Practice. London: Sage.

Sahlberg, Pasi. 2012. "How GERM is infecting schools around the world?" https://pasisahlberg.com/text-test/

Sherrill, Robert. 1995. "Citizen Murdoch: Buying his way to a Media Empire," The Nation, 260 (21): p. 750, 749-54.

Silver, Harold. 1990. Education, Change and the Policy Process. Barcombe: Falmer Press.

Slee. Roger. 2018. Inclusive Education Isn't Dead, It Just Smells Funny. Abingdon:

Routledge.

Wilson, John, Anthony Webster and Rachael Vorberg-Rugh. 2013. Building Co-operation: A Business History of the Co-operative Group 1863-2013. Oxford: Oxford University Press.

Wilson, Mervyn. 2016. Contribution to seminar at UCL Institute of Education.

Wintour, Patrick. 2008. "Balls to Set Out Vision of 100 Schools Becoming Co-operative Trusts, Guardian, September 11.

Woodin, Tom. 2011. "Co-operative Education in the Nineteenth and Early Twentieth Centuries: Context, Identity and Learning”, in Anthony Webster, Linda Shaw, John K. Walton, Alyson Brown and David Stewart. Chapter 5. The Hidden Alternative: Co-operative Values, Past, Present and Future. Manchester: Manchester University Press.

Woodin, Tom. 2015. ed. Co-operation, Learning and Co-operative Values. London: Routledge.

Woodin, Tom, David Crook and Vincent Carpentier. 2010. Community and Mutual Ownership - a Historical Review. York: Joseph Rowntree Foundation.

Woods, Philip A. 2015. "Co-operativism as an Alternative: Choice, Assimilation and Challenge”, Chapter 4 in Woodin, Tom. 2015. ed. Co-operation, Learning and Co-operative Values. London: Routledge. 
World Co-operative Monitor. 2016. Exploring the Co-operative Economy. ICA and Eurisce https://monitor.coop/sites/default/files/publication-files/wcm2016-final-web1602953294.pdf.

Yeo, Stephen. Ed. 1988. New Views of Co-operation. London: Routledge.

Interviews cited

Headteacher Pine School, 2014

Headteacher, Ash School, 2012

Headteacher, Larch School 2014

Teacher, Larch School 2014

Headteacher, Oak School 2012

Headteacher, Alder School 2015

Co-op organiser 2010

Co-operative speaker, seminar, 2016

Co-ordinator 2010 and 2016

Organiser 2018 